Introduction

\title{
Women's Lives in Colonial AND Postcolonial Maghrib
}

\author{
Etty Terem
}

\begin{abstract}
Aвstract: This introduction to the special issue highlights dominant approaches to the study of women's and gender history in colonial and postcolonial Maghrib. Moreover, it delineates the analytical agenda that frames our inquiry, and reviews the essays in this collection.
\end{abstract}

Keywords: colonialism, France, gender, Maghrib, postcolonialism, women

Over the past two decades, historical studies of France's colonies in the Maghrib have deepened our knowledge of the meaning of colonialism and its myriad legacies in the colonies and metropole. By employing new methodologies, adopting new theoretical approaches, studying new sources, and revisiting old ones, historians, inspired by postcolonial theorists, have offered a considerable reevaluation of the history and historiography of the various colonies and France. ${ }^{1}$ Despite growing interest in colonial Maghrib, less consideration has been given to the study of women's and gender history in colonial and postcolonial contexts. ${ }^{2}$ Informed by important scholarship on the Middle East, early studies in this field focused on French discourses on indigenous women and colonial projects of reform. Such studies have drawn particular attention to the perspectives of women settlers of European descent and the active roles they played in the education of Muslim girls. ${ }^{3}$ An even smaller number of studies examined the role of women in resistance to patriarchal domination and colonial rule, and their involvement in nation building. ${ }^{4}$ The essays in this special issue seek to follow up on these early contributions in women's and gender history, drawing attention to the relations between colonial and postcolonial contexts. Most importantly, our goal here is to connect 
the extensive work done in colonial studies and Middle East history with women's and gender history in the Maghrib.

Two unifying assumptions govern our approach to the study of the colonial Maghrib. First, we understand colonialism as one aspect of the global process of modernity that shaped the material and epistemological conditions of the Maghrib (and Europe more generally). That way, we do not conceive of modernity as a normative state "originating integrally in Europe and then ... transplanted or expanded" on to the Maghrib. Instead, we understand modernity as a "global relational reordering" in which different experiences emerged in different localities. ${ }^{5}$ Nor do we consider the transformations that emerged under modern conditions as completely due to European colonialism. The essays which follow underscore the critical role indigenous actors played in shaping the process of becoming modern. In particular, we demonstrate how Maghribi people consciously used new ideas and practices as well as their own interpretations and understandings, thus investing modernity with novel meanings. In this sense, we think about colonialism and the colonial state as one aspect of modernity in the Maghrib (alongside a wide range of resources, institutions, habits, etc.).

Second, in exploring the new historical conditions that constituted that modern Maghrib, we sought to move beyond an essentialist approach that emphasizes an inherent and stable divide between the European colonizer and the indigenous colonized. Instead, we are interested in the important interconnections and mutually constitutive links that shaped the Maghrib and France. Some of the links we delineate are between the colonizer and the colonized, the local and the regional, the metropole and the colony, and the colonial and the post-colonial periods. Our view, informed by earlier efforts of many outstanding scholars, is that while colonial regimes often sought to produce their own structures of domination and policies of rule in the colonies, colonial projects themselves were never coherent or all-powerful. In the words of Ann Laura Stoler and Frederick Cooper, "Europe's colonies were never empty spaces to be made over in Europe's image or fashioned in its interests; nor, indeed, were European states self-contained entities that at one point projected themselves overseas." ${ }^{6}$ Considered in this way, we investigate the transformations that reshaped the modern Maghrib as the product of profound and complex interactions between the global and the local.

One of the most prolific fields of research that has a profound effect upon our understanding of colonialism is women's and gender history. A range of studies in various regions, including South Asia, Africa, and the Middle East, have demonstrated the interplay between gender and policies of colonial rule, efforts at modernization, nationalist movements, 
state-building, and empire-building projects. ${ }^{7}$ Specifically, our concern is with exploring the material and epistemological transformations that shaped the new conditions in which indigenous societies lived in the colonial and postcolonial Maghrib and the ways they constituted modern identities on both sides of the Mediterranean. Our analysis follows indigenous actors, men and women, as they navigated their changing world. The principal theoretical issue that the following essays interrogate is the relationships between colonizer and colonized. The authors here sought ways to go beyond narrow terms of colonial domination/indigenous resistance or collaboration and explore other explanations.

The five essays draw attention to the importance of women and gender to the development of patriarchy, medicine, law, social reform, and state- and empire-building. We move beyond simply affirming the unity of "le fait colonial" to explore "the intellectual, social, and political effects of the intrusion of foreign powers, as well as their limits as people drew on their own cultural resources to respond." ${ }^{8}$ Specifically, we attend to practices of interaction, negotiation, contestation, and mediation. Moreover, we are mindful of the multiple historicities of Maghribi societies, before and after military occupation and colonization, and thus are interested in highlighting domains of action not directly motivated by colonialism, but located instead in the persistence of local laws and conventions. In this context, we heed the call to situate the "colonial moment" within the longue durée. ${ }^{9}$ We argue that the changes that created the modern Maghrib were deeply affected by indigenous thought and practice as much as by the colonial state and its policies. Equally important are the regional context and the transimperial connections that played an important role in the constitution of modern identities.

In his article "Muslim Notables, French Colonial Officials, and the Washers of the Dead: Women and Gender Politics in Colonial Algeria," Augustin Jomier examines the development of patriarchy in colonial Mzab (1882-1962), a Berber speaking and Ibadi Muslim community, situated in the northern portion of the Algerian Sahara. He interrogates a familiar colonial myth that assumes the persistence of patriarchal norms and gender relations from the pre-colonial to the colonial periods and emphasizes France's significant contribution to the emancipation of indigenous women. Jomier calls, instead, for a far more complex understanding of colonial agency in the reordering of patriarchy. He exposes the ways in which interactions between colonial administrators, French ethnographers, and local (male and female) elites simultaneously enhanced and reshaped male domination over women and gender segregation. In particular, he illuminates the key role played by a Mzabi group of learned and pious women in disseminating notions of female domesticity and 
defending patriarchal gender relations, as a means of bolstering their own social influence and increasing their prestige (even though their powerful roles and rights were progressively circumscribed). Jomier argues convincingly that, following the introduction of colonial rule over the region in 1882, "Mzabi women came to embody the Ibadi community's purity" simultaneously vis-à-vis the French as well as the Muslim Algerian population. Thus, at the same time that women were identified as "custodians of the community's identity," their visibility and mobility in the public sphere were restricted and their education was checked "to prevent any kind of external attack or influence on them." If Mzabi women were to resist these representations and gender practices, he writes, "they would have engendered their whole community, playing the colonizers' game." Therefore, women themselves "played according to the Ibadi male rule and had to accept the reinforcement of a patriarchal domination."

In "Françoise Légey and Childbirth in Morocco," Jonathan G. Katz offers a critique of the position that frames the emergence of modern medicine in Morocco in terms of the conventional (and controversial) center-periphery model. Specifically, he challenges the view that humanitarian and philanthropic European doctors and nurses, seeking to modernize the Protectorate, spread Western medical methods and technologies that ultimately replaced indigenous medical traditions with Western institutions and standards. Katz examines the career and legacy of Françoise Légey, a French physician, who worked in Marrakesh between 1910 and 1935. At her initiative, a maternity hospital and milk dispensary were established to serve the European community as well as Moroccan Muslims and Jews, and an ambitious project to train "modern" indigenous midwives and supplant "traditional" practices was developed. Katz stresses that the efforts of Légey (and other European female doctors) undermined the role of indigenous midwives and contributed to the view that biomedicine and indigenous medical traditions are rival systems, both during and after formal colonial rule. Nonetheless, he contends that "the dream of training a large cadre of Moroccan midwives" and the colonial efforts to substitute European biomedical practices for indigenous medicine were largely frustrated. Instead, "European medicine disproportionately attracted the Jewish minority," further contributing "to the Jewish alienation from the Muslim majority." Moreover, he emphasizes "the landscape of medical pluralism" in contemporary Morocco and shows that the recourse to biomedicine does not deny indigenous traditions of medicine and healing outright. In recognizing the resilience of these traditions, Katz stresses that Europe's influence on Morocco was never complete and modernity does not follow a simplistic either/or logic. 
Sarah Ghabrial's article, "Illegible Allegations: Navigating the Meanings of Rape in Colonial Algeria," considers a set of rape cases brought before the French colonial criminal court in Blida in the early twentieth century. Ghabrial approaches law as a fluid and negotiated space (much less stable and systematized than the colonial state claimed to uphold) and illuminates indigenous resourcefulness and pragmatism in navigating a complex legal terrain. In practice, she suggests, indigenous litigants often used various venues and diverse codes of law to secure a favorable judgement in their case; they might present French doctor's reports as evidence in the qadi court, and then argue their case in the colonial court, relying on Islamic jurisprudence. Ghabrial argues that as Muslim Algerian women appeared before the colonial courts, they came with a set of "definitions of and remedies for forced or unlawful sex" that confronted colonial law and its approach to rape. She demonstrates that in requesting monetary compensatory remedies for rape (usually in an amount equivalent to the dower), Algerian women invoked local norms (customary practices or sharī'a-based prescriptions). However, in considering rape cases, colonial jurists and judges based their rulings on French penal law as well as their own understandings of Islamic law. The combined effect of these intertwined processes resulted in the codification of marriage as a compensation for rape in Algeria. Further, Ghabrial stresses that the medicalization of law and criminal investigations complicated prosecution. As French legal and medical concepts were implanted in Algeria, they reflected colonial objectives. Muslim women and girls were the object of intensified suspicion, and as a result, were routinely discredited by "evidence" from their own bodies. "As whatever prior distinctions between abduction, seduction, elopement, and rape fell away, the remedy of marriage devised for such cases came to stand in as 'compensation' for non-consensual sex and violent assault." In this way, colonial agency resulted in reshaping the legal and social meaning of rape.

Etty Terem's “Educating Women, Recasting Patriarchy: Becoming Modern in Colonial Morocco" examines the development of agendas of social and cultural reform as the basis for national renewal. In seeking to shift the explanation of change in colonial Morocco away from the binary opposition between the colonizer/colonized, Terem explores "other important relations and tensions at work central to the rise of modern epistemology and subjectivity." Building upon this framework, she situates a project of reform in girls' education within struggles and divides among Moroccans themselves. Specifically, she suggests that the discourse about female education was rooted in a broader debate about the effective methods and strategies for reorganization of the education system and pedagogical restructuring that involved important segments of the 
Moroccan power elite and intelligentsia. Moreover, she argues, "In debating different approaches to educational modernization, Moroccans pondered old institutions and customs, discussed the consequences of social change, and consciously articulated their hopes and expectations for their community, thus actively engaging their changed world." In uncovering diverse concerns, agendas, and visions towards the modernization of Moroccan state and society, Terem stresses that engaging with the colonial state and its modernizing reforms "constituted but one aspect of how Moroccans negotiated their world."

In the final article, "Transnational Intimacies and the Construction of the New Nation: Tunisia and France in the 1960s," Amy Kallander locates new cultural imaginings about love and marriage within the articulation of national culture and identity in the early postcolonial era. Her attention to more popular forms of print culture opens up a new world of writings: Women's magazines in Tunisia and France. Her study of "advice columns" enables entry into domains of "urban, educated, and middle-class" women, who discussed love and "gender roles within dating and marriage." In both nations, she argues, the idealization of romantic love and companionate marriage was connected with development projects and nationalist goals. In Tunisia, notions of romance and marriage of choice were crystalized within modern politics that embraced women's rights, gender equality, and national liberation. In France, national regeneration centered on the marital couple and the modern wife. Moreover, Kallander highlights critical and negative emphasis on interracial marriage as a sign of further delineation of national borders. This, she argues, disrupted "women's emancipation and the liberal notion of choice" and demonstrated that "relations of coloniality between the former colony and the French metropole" persisted in the postcolonial context.

\section{Notes}

*I owe special thanks to this issue's contributors for their careful reading and valuable comments on earlier drafts of this article.

1. It is significant to note here that these works have not only transformed our understanding of the colonial Maghrib, but have exposed the critical effects of colonialism on France itself. For some recent examples, see Benjamin Claude Brower, A Desert Named Peace: The Violence of France's Empire in the Algerian Sahara, 1844-1902 (New York: Columbia University Press, 2005); Todd Shepard, The Invention of Decolonization: The Algerian War and the Remaking of France (Ithaca: Cornell University Press, 2006); Muriam Haleh Davis and Thomas Serres, eds., North Africa and the Making of Europe: Governance, Institutions and Culture (New York: Bloomsbury Academic, 2018); Judith Surkis, Sex, Law, 
and Sovereignty in French Algeria, 1830-1930 (Ithaca: Cornell University Press, 2019).

2. By contrast, gender history in scholarship on the Eastern Mediterranean and Iran has been a dynamic and important field for research. See, "Roundtable: Gendering Middle East History," International Journal of Middle East Studies $48: 3$ (2016), 551-588.

3. For some of the best examples of this scholarship, see Malek Alloula, The Colonial Harem, trans. Myrna Godzich and Wlad Godzich (Manchester: Manchester University Press, 1987); Julia Clancy-Smith, "Islam, Gender, and Identities in the Making of French Algeria, 1830-1962," in Domesticating the Empire: Race, Gender, and Family Life in French and Dutch Colonialism, eds. Julia Clancy-Smith and Frances Gouda (Charlottesville: University Press of Virginia, 1998), 154-74; idem, "A Woman Without Her Distaff: Gender, Work, and Handicraft Production in Colonial North Africa," in A Social History of Women and Gender in the Modern Middle East, eds. Margaret L. Meriwether and Judith E. Tucker (Boulder: Westview Press, 1999), 25-61; idem, "L'école Rue du Pacha à Tunis : l'éducation de la femme arabe et 'la Plus Grande France' (1900-1914)," Clio: Femmes, Genre, Histoire 12 (2000): 33-55; idem, "Envisioning Knowledge: Educating the Muslim Woman in Colonial North Africa, c. 1850-1918," in Iran and Beyond: Essays in Middle Eastern History in Honor of Nikki R. Keddie, eds. Rudi Matthee and Beth Baron (Costa Mesa, California: Mazda, 2000), 99-118; Jeanne M. Bowlan, "Civilizing Gender Relations in Algeria: The Paradoxical Case of Marie Bugéja, 1919-39," in Domesticating the Empire: Race, Gender, and Family Life in French and Dutch Colonialism, eds. Julia Clancy-Smith and Frances Gouda (Charlottesville: University Press of Virginia, 1998), 175-92; Ryme Seferdjeli, "French 'Reforms' and Muslim Women's Emancipation during the Algerian War," Journal of North African Studies 9:4 (2004), 19-61; Sara L. Kimble, "Emancipation through Secularization: French Feminist Views of Muslim Women's condition in Interwar Algeria," French Colonial History 7 (2006), 109-28; Ranjana Khanna, Algeria Cuts: Women and Representation, 1830 to the Present (Stanford: Stanford University Press, 2007); Rebecca Rogers, A Frenchwoman's Imperial Story: Madame Luce in Nineteenth-Century Algeria (Stanford: Stanford University Press, 2013).

4. Ilhem Marzouki, Le mouvement des femmes en Tunisie au XXème siècle: féminisme et politique (Paris: Maisonneuve et Larose, 1993); Marina Lazreg, The Eloquence of Silence: Algerian Women in Question (New York: Routledge, 1994); Zakya Daoud, Féminisme et politique au Maghreb: soixante ans de lutte, 1930-1992 (Casablanca : Eddif, 1995); Souad Bakalti, La femme tunisienne au temps de la colonisation: 1881-1956 (Paris: L'Harmattan, 1996); Julia Clancy-Smith, Rebel and Saint: Muslim Notables, Populist Protest, Colonial Encounters (Algeria and Tunisia, 1800-1904) (Berkeley: University of California Press, 1997); Dalenda Larguèche, ed., Histoire des femmes au Maghreb: Culture matérielle et vie quotidienne (Tunis: Centre de Publication Universitaire, 2000); Ryme Seferdjeli, "Rethinking the History of the Mujahidat during the Algerian War: Competing Voices, Reconstructed Memories, and Contrasting Historiographies," Interventions 14:2 (2012), 238-55; Natalya Vince, Our Fighting Sisters: Nation, Memory and Gender in Algeria, 1954-2012 (Manchester: Manchester University Press, 2015). 
5. James McDougall, "Modernity in 'Antique Lands': Perspectives from the Western Mediterranean," Journal of the Economic and Social History of the Orient 60 (2017), 1-17, here 6.

6. Ann Laura Stoler and Frederick Cooper, "Between Metropole and Colony: Rethinking a Research Agenda," in Tensions of Empire: Colonial Cultures in a Bourgeois World, eds. Frederick Cooper and Ann Laura Stoler (Berkeley: University of California Press, 1997), 1-56, here 1.

7. In Middle East studies particularly, see, for example, Beth Baron, Egypt as a Woman: Nationalism, Gender, and Politics (Berkeley: University of California Press, 2005); Elizabeth Thompson, Colonial Citizens: Republican Rights, Paternal Privilege, and Gender in French Syria and Lebanon (New York: Columbia University Press, 2000); Lila Abu-Lughod, ed., Remaking Women: Feminism and Modernity in the Middle East (Princeton: Princeton University Press, 1998).

8. Emmanuelle Saada, "More Than A Turn? The 'Colonial' in French Studies," French Politics, Culture \& Society 32:2 (2014), 36.

9. Isabelle Grangaud and M'hamed Oualdi, "Tout est-il colonial dans le Maghreb? Ce que les travaux des historiens modernistes peuvent apporter," Revue d'histoire moderne \& contemporaine 63:2 (2016), 233-54; M'hamed Oualdi, "Une succession d'empires: Les historicités d'une société maghrébine (1860-1930)," Annales HSS 72:4 (2017), 1-29. 